\title{
Den globale helsearkitekturen - til nytte for alle? 迷
}

\author{
Sikkerhet for helsen forutsetter samarbeid på tvers av landegrensene. Verdens helseorganisasjon ble \\ etablert som redskap for å mestre grenseoverskridende helsetrusler, forhandle frem normer og skape et \\ felles grunnlag for deling av informasjon, kunnskap og ressurser. Denne rollen utfordres i dag av et mang- \\ fold av aktører og initiativer. Helsetilstanden påvirkes også av en rekke mellomstatlige prosesser som ikke \\ blir styrt av helsemyndighetene.
}

Engelsk oversettelse av hele artikkelen på www.tidsskriftet.no

\section{Sigrun Møgedal}

sigrun.mogedal@kunnskapssenteret.no

Nasjonalt kunnskapssenter for helsetjenesten

Benedikte Alveberg

Helse- og omsorgsdepartementet

Carmen Pereira

Helsedirektoratet

Institusjoner og organisasjoner, samarbeidsog beslutningsstrukturer som knytter ulike aktører sammen i en mer eller mindre etablert relasjon med helse for verdens befolkning som hovedmål, omtales ofte samlet som «den globale helsearkitekturen» (1).

Tilsvarende kan man snakke om en nasjonal helsearkitektur med institusjoner, aktører og beslutningsprosesser rettet mot helseformål for landets befolkning. Den globale helsearkitekturen kan ikke ses isolert fra den nasjonale, den nasjonale ikke fra den lokale. Mange aktører og interesser er representert på alle nivåer. Samtidig har hvert nivå sin egen dynamikk og må forstås i sin egen sammenheng.

Verken den globale eller den nasjonale helsearkitekturen er statiske størrelser, det kommer stadig nye aktører, behov og krav. Det foregår gjennomgripende reformer av forholdet mellom offentlig og privat, strukturer for finansiering, samhandling og delegering, profesjon og marked. Globalt kommer i tillegg stor ulikhet mellom landenes behov og interesser, uten at man har en samlende global styringsinstans med myndighet til å ta helhetlige beslutninger.

Arkitektur som byggekunst speiler sin tid og knytter sammen idé og funksjonalitet i et helhetlig byggverk som skal stå lenge. Den globale helsearkitekturen reflekterer også sin tid. Verdens helseorganisasjon var det første byggverket, med samarbeid mellom nasjonalstatene som bærende idé. Siden har et mangfold av aktører og interesser kommet inn og i rask utbyggingstakt skapt en rekke konstruksjoner over en relativt kort tidsperiode - uten klar arealplanlegging, renovasjonsløsninger eller overbygning.

Det store spørsmålet er om vi har gode nok redskaper til å sette agendaen, koordinere de ulike aktørene og styre det politiske, tekniske og økonomiske samarbeidet for å kunne mestre de helseutfordringene verden står overfor.

\section{Hva særpreger de globale helseutfordringene?}

Utgangspunktet for global helse er at alle mennesker, uten unntak, skal ha rett til tjenester, teknologi og kunnskap som møter deres behov for å opprettholde og styrke helsen. Helse forstås som grunnleggende for fred og sikkerhet, sosial trygghet og samfunnsøkonomi og er avhengig av et optimalt samarbeid mellom individer, sivilsamfunn og stat.

\section{«Offentlige myndig- heter, privat sektor og sivilsamfunn har felles ansvar for den globale helsen»}

Stater har ulik evne til å bygge opp folkehelsen og kontrollere sykdom, og de svakeste leddene kan skape særlig helserisiko for alle land. Erkjennelsen av vår felles sårbarhet skaper økt forståelse for vårt felles ansvar. Samtidig ser vi at offentlige myndigheter ikke alene kan skape helsesikkerhet, verken nasjonalt eller globalt. I økende grad påvirkes sosiale og økonomiske helsedeterminanter av multinasjonal privat økonomisk virksomhet, migrasjon og kommunikasjon. Offentlige myndigheter, privat sektor og sivilsamfunn har felles ansvar for den globale helsen.

At helsetrusler uhyre raskt kan bli globale, blir stadig mer tydelig - med tettere kommunikasjon over grensene, globalisert industri og økonomi og store klimaendringer. Vi trenger en mellomstatlig spesialisert helseorganisasjon som kjerne i den globale helsearkitekturen, men dette er ikke tilstrekkelig som redskap for alles helse siden mestring av helsetrusler og beslutninger som angår helse også berører politikkområder som i høy grad er påvirket av andre aktører og andre mellomstatlige prosesser.

\section{Arenaer og aktører}

WHO-konstitusjonen, vedtatt i 1946, startet med vektlegging av smittsomme sykdommer (2). Under den kalde krigen ble et viktig mål å etablere et best mulig vern mot uheldig «politisering» av helsespørsmål. Konstitusjonen har siden vært oppdatert flere ganger og trekker nå opp et langt bredere rammeverk av prinsipper for mellomstatlig samarbeid.

Som FNs spesialorganisasjon for helse har WHO sentrale funksjoner på normative områder, i helseovervåking, global kunnskapsforvaltning og i kapasitetsbygging innen nasjonal helseforvaltning i utviklingsland. Et særtrekk ved WHO er organiseringen gjennom seks sterke regionalkontorer med betydelig autonomi. De disponerer $60-70 \%$ av WHOs ressurser og har også hovedansvaret for WHOs landkontorer.

WHO står helt sentralt i mellomstatlige forhandlinger om standarder og avtaler. Det internasjonale helsereglementet (2005) (3), pandemirammeverket (2011) (4) og koden for internasjonal rekruttering av helsearbeidere (2010) (5) er eksempler på viktige gjennomslag i slike forhandlinger.

Men også andre FN-organisasjoner har viktige funksjoner innen global helse. FNs befolkningsfond (UNFPA) har et særlig ansvar knyttet til reproduktiv helse og befolkningspolitikk, mens FNs barnefond 
(UNICEF) har barnehelse i sitt mandat. FNs arbeid mot aids samordnes gjennom et felles sekretariat for de aktuelle FN-organisasjonene (UNAIDS), som overvåker utviklingen av hivepidemien og står for globalt lederskap på området. Verdensbanken, det internasjonale pengefondet (IMF) og regionalbankene er viktige premissleverandører og finansieringskilder for helsesystemer i utviklingsland.

\section{Fra primærhelsetjeneste} til konkrete helsemål

I 1990-årene dreide internasjonalt helsearbeid seg hovedsakelig om utviklingshjelp, ledet av WHO, UNICEF og UNFPA, samt store statlige utviklingsprogrammer med USA (United States Agency for International Development), England (UK Department for International Development ), Tyskland (Deutsche Gesellschaft für Internationale Zusammenarbeit), Nederland og de nordiske land i front. Primærhelsetjenesten sto i fokus. Man la vekt på barnehelse, vaksinasjoner og reproduktiv helse, $\mathrm{i}$ økende grad også på helsereformer og koordinerte helsesektorsatsinger med WHO og Verdensbanken i ledende roller.

Men resultatene var ikke overbevisende. Rundt tusenårsskiftet rådet utålmodighet for å oppnå konkrete mål. WHO så behovet for nye politiske grep og bidro til å lansere flere tunge, nye initiativer, blant annet Roll Back Malaria (RBM) og vaksinealliansen GAVI. Slik ble nye aktører engasjert, aktører fra både privat og frivillig sektor. FNs tusenårserklæring med tre helserelaterte tusenårsmål (barnehelse, mødrehelse og et samlet mål for aids, tuberkulose og malaria) skapte grobunn for å mobilisere særskilt for disse målene. En egen politisk erklæring for hiv og aids ble vedtatt i FN i 2001, og FNs generalsekretær engasjerte seg i forslaget om å opprette et eget fond for å mestre denne utfordringen. G8-landene tok dette videre til sitt møte i Okinawa. Det ble grunnlaget for det globale fondet for aids, tuberkulose og malaria (GFATM), som ble etablert i 2002 .

GAVI og GFATM har det til felles at de har disponert store midler og frembrakt resultater som har vært overbevisende for givere, og de er nå etterspurt som partnere for land som trenger bistand. De er i dag selvstendige stiftelser registrert i Sveits, med egne styrer der representanter for stater sitter sammen med representanter fra privat sektor og aktører fra sivilsamfunnet, inkludert brukerrepresentanter. Begge har forpliktet seg til å arbeide innenfor FN-systemets normative rammer. Samtidig har mange bekymret seg over at ensidig vektlegging av vaksinering og enkelte sykdommer har ført til nedprioritering av investeringer i infrastruktur, personell og andre grunnleggende elementer $i$ et helsesystem.

Private aktører som Bill and Melinda Gates' stiftelse er blitt betydningsfulle innen finansiering, prioritering og veivalg for global helse. Behovet for å skape synergier og felles forståelse på tvers av ulike aktører var grunnlaget for det uformelle samarbeidsorganet som kalles H8 (6). Her kommer folk fra ledernivåene i WHO, UNICEF, UNFPA og UNAIDS sammen med Verdensbanken, GAVI, GFATM og Gates-stiftelsen. Hva dette organet betyr, er fortsatt uklart, da det er et forum som ikke er åpent for innsyn, ikke har som formål å bedre den globale samhandlingen og heller ikke fatter bindende beslutninger.

I arbeidet med tusenårsmålene og med årlige rapporter (7) og resolusjoner (8) om sammenhengen mellom utenrikspolitikk og helse er FNs generalforsamling og generalsekretærens kontor i økende grad blitt en viktig aktør innen helsearkitekturen, synliggjort i generalsekretærens strategi for kvinners og barns helse (9).

G8-landene har de siste ti årene kanalisert mye av sin bistand gjennom globale initiativer som GAVI og GFATM. Dette har bidratt til at andre giverland også har prioritert disse kanalene. Sivilsamfunnets aktører og privat sektor har samtidig fått muligheter til styredeltakelse og til å påvirke beslutningene, noe de ikke har anledning til i WHO. Private stiftelser og ikke-statlige organisasjoner har slik fått en viktig rolle når det gjelder finansiering og styring av helseinnsatser.

\section{Knoppskyting}

I kjølvannet av de store initiativenes suksess har det utviklet seg nye partnerskap og allianser for særlige formål, slik som den internasjonale ordningen for innkjøp av legemidler (UNITAID), partnerskapet for mødre-, nyfødt- og barnehelse (PMNCH), partnerskapet for helseinformasjon (Health Metrics Network) og den globale helsearbeideralliansen (GHWA). De fleste av disse har som hovedoppgave å mobilisere ulike

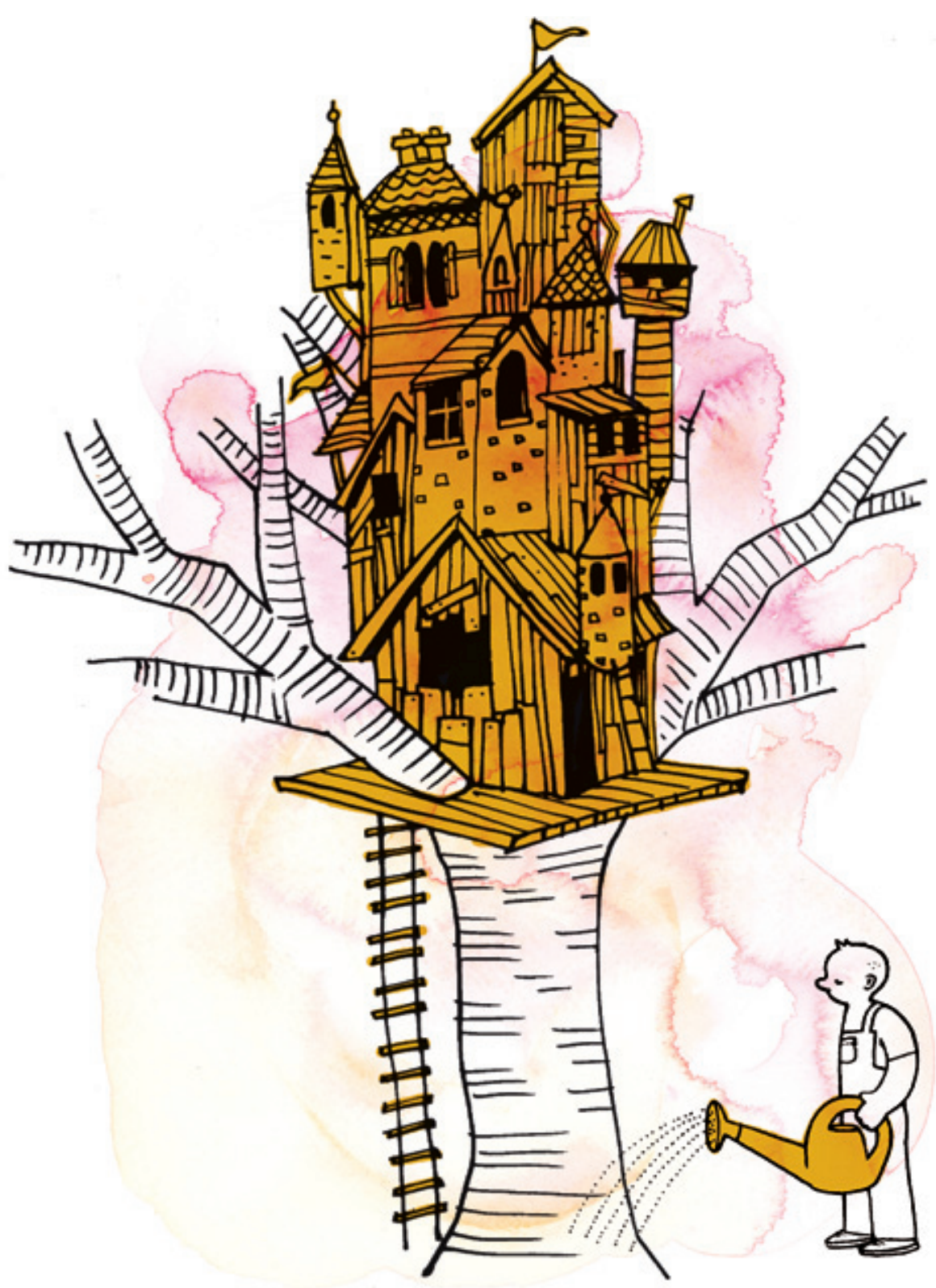


aktører for felles mål, men er ikke finansieringsinstrumenter. Mange av partnerskapene har WHO som vertskap, men har egne styrer. Knoppskytingen av slike initiativer har skapt en tendens til at hver ny idé genererer et nytt partnerskap. Dette er etter hvert blitt en stor utfordring for WHO.

Det har vist seg svært komplisert å få oversikt over midlene gjennom ulike kanaler for globale helseinnsatser. Organisasjonene registrerer finansiering på ulike måter, og det er ikke lett å tolke tallene. Noe handler om overføringer til bistand for fattige land, andre tall omfatter investeringer $i$ helse globalt, inkludert drift av organisasjonene. Ut fra informasjon som nylig er publisert (10), er det imidlertid klart at USA alene er en hovedaktør og at midlene gjennom FN-systemet og finansinstitusjonene ikke er ubetydelige sammenliknet med de store fondene GAVI og GFATM. Manglende oversikt over finansieringen er en stor utfordring for styring og effektivisering $i$ en uoversiktlig arkitektur.

\section{Nødvendig med kobling \\ til andre arenaer}

I FN er det kun medlemsstater som kan delta i de styrende organer. Til forskjell fra WHO, der helseministrene sitter i førersetet, er det utenriksmyndighetene som ivaretar landenes interesser i FNs fond og programmer og i FNs generalforsamling, råd og komiteer. I de internasjonale finansinstitusjonene er det finansdepartementene eller nasjonalbankene som styrer. Medlemsland må derfor ha et avklart forhold til hvordan helse er i all politikk og hvordan de forskjellige departementer kan bidra til felles mål og koherent politikk på ulike arenaer. Flere land har nettopp av denne grunn laget egne nasjonale strategier for global helse, forankret på regjeringsnivå (11).

Helsediplomati er i ferd med å bli en viktig del av både helse- og utenrikspolitikken (12). Migrasjon, konflikter og kriser medfører helseutfordringer som krever egne regler for internasjonal håndtering. Retten til helse er knyttet opp til forhandlinger og avtaler om andre menneskerettigheter, og ernæring/matsikkerhet inngår i forhandlinger om hele matvarekjeden og i mange internasjonale institusjoners arbeid. Tilgang til legemidler er et særlig utfordrende tema for helsediplomatiet $\mathrm{i}$ internasjonale forhandlinger på handelsområdet. Disse politikkområdene har store utfordringer knyttet til samhandling om virkemidler, interesser og makt nasjonalt og internasjonalt. I helsearkitekturen er det derfor behov for institusjonelle relasjoner også til mellomstatlige institusjoner som ikke har helse som sitt primære mandat, både innenfor og utenfor FN-systemet.

\section{Styringsutfordringene i den globale helsearkitekturen}

WHOs posisjon som autoritet for å styre og koordinere internasjonalt helsearbeid er i dag sterkt utfordret, både når det gjelder finansiering og organisering (13). Et større antall aktører, press på finansiering, økende vektlegging på resultater og bredere samarbeid mellom statlige, ikke-statlige og private instanser tvinger frem en diskusjon om hvordan styring av det WHO-baserte mellomstatlige samarbeidet kan gjennomføres på en bedre måte og bedre koblet mot andre arenaer og prosesser. Her foregår det i dag nytenkning og reformarbeid innenfor WHO, i de ulike globale helseinitiativene og i bredere dialog om global styring av mellomstatlig samarbeid (14).

WHO-konstitusjonens prinsipper er likevel fortsatt godt egnet til bruk som referanseramme for en mer effektiv global helsearkitektur og et mer effektivt FN som del av denne. Det er stor enighet om WHOs berettigelse og relevans som «kjernen» $\mathrm{i}$ helsearkitekturen og som hovedarena for mellomstatlig samarbeid for helseformål gjennom forhandlinger og forpliktende samarbeid. Spørsmålet er hvordan denne kjernen står i samspillet med mangfoldet av ikke-statlige aktører og initiativer som kan bidra med ressurser og innovasjon og være pådrivere og korrektiver.

Utfordringen er ikke først og fremst en mer enhetlig global helsearkitektur, men større oppmerksomhet rundt hva som i dag hindrer effektiv ressursstyring og resultatrettet samarbeid mellom ulike aktører og arenaer. Det er behov for nytenkning og forenkling, slik at man kan dra bedre nytte av mangfoldet av aktører, i kombinasjon med forpliktende mellomstatlig samarbeid og samstemt helsefremmende politikk.

\section{Sigrun Møgedal (f. 1943)}

er lege og spesialrådgiver ved Kunnskapssenteret. Hun har vært Norges ambassadør for hiv/aid og globale helseinitiativ, seniorrådgiver i Norad og direktør ved Diakonhjemmets internasjonale senter

Ingen oppgitte interessekonflikter.

\section{Benedikte L. Alveberg (f. 1974)}

har mastergrad i statsvitenskap fra Lausanne og mastergrad i utviklingsstudier fra Genève og er seniorrådgiver i Helse- og omsorgs- departementet. Hun har arbeidet sju år i Verdens helseorganisasjon og har hatt konsulentoppdrag for UD og NORAD.

Ingen oppgitte interessekonflikter.

\section{Carmen Pereira (f. 1947)}

er fra Angola og har bodd i Norge siden 1966. Hun er m. phil. og cand.real. og er for tiden seniorrådgiver i Helsedirektoratets avdeling for global helse.

Ingen oppgitte interessekonflikter.

\section{Litteratur}

1. Fidler DP. Architecture amidst anarchy: global health's quest for governance. Global Health Governance 2007; 1: 1-17.

2. Constitution of the World Health Organization http://apps.who.int/gb/bd/PDF/bd47/EN/ constitution-en.pdf (18.7.2011)

3. International health regulations. 2. utg. Genève: WHO, 2005. http://whqlibdoc.who.int/publications/ 2008/9789241580410 eng.pdf (19.6.2011).

4. Pandemic influenza preparedness: sharing of influenza viruses and access to vaccines and other benefits. Genève: WHO, 2011. http://apps.who.int/ gb/ebwha/pdf_files/WHA64/A64_8-en.pdf (19.6.2011).

5. WHO global code of practice on the International recruitment of health personnel. Genève: WHO, 2010. www.who.int/hrh/migration/code/ code_en.pdf (19.6.2011).

6. St.prp. nr. 1 (2008-2009) for budsjettåret 2009 . Kap. 169. Globale helse- og vaksineinitiativ. www.regjeringen.no/pages/2114213/PDFS/ STP200820090001_UDDDDPDFS.pdf (18.7.2011).

7. Global health and foreign policy. A/65/L.27. New York: FNs generalforsamling, 2010. www.un.org/ ga/search/view_doc.asp?symbol=A/65/L.27 (18.7.2011).

8. Global health and foreign policy. Note by the Secretary-General A/65/399. New York: FNs generalforsamling, 2010. www.un.org/ga/search/ view_doc.asp?symbol=A/65/399\&referer=http:// www.un.org/Docs/journal/Fr/latestf.pdf\&Lang=E (18.7.2011).

9. Global Strategy for Women's and Children's Health. United Nations Secretary-General Ban Ki-moon, 2010. www.un.org/sg/hf/ Global StategyEN.pdf (18.7.2011).

10. Murray CJ, Anderson B, Burstein R et al. Development assistance for health: trends and prospects. Lancet 2011; 378: 8-10

11. Health is global. A UK government strategy 2008-13. London: Department of Health, 2008. www.dh.gov.uk/prod consum dh/groups/ dh_digitalassets/@dh/@en/documents/ digitalasset/dh_088753.pdf (18.8.2011).

12. Sandberg KI, Andresen S, Stein SH et al. Helse som utenrikspolitikk. Tidsskr Nor Legeforen 2011; 131: akseptert for publisering

13. The future of financing for WHO. World Health Organization: reforms for a healthy future. Report by the Director-General. A/64/INF.DOC./5. Genève WHO, 2011. http://apps.who.int/gb/ebwha/ pdf_files/WHA64/A64_ID5-en.pdf (18.7. 2011).

14. Ng NY, Ruger JP. Global health governance at a crossroads. Global Health Governance 2011; 3: $1-37$. 